\title{
MEASURING URBAN TRAFFIC CONGESTION - A REVIEW
}

\author{
Amudapuram Mohan Rao ${ }^{1}$, Kalaga Ramachandra Rao ${ }^{2}$ \\ ${ }^{1}$ Central Road Research Institute, Mathura Road, PO CRRI, New Delhi - 110 020, India \\ ${ }^{2}$ Indian Institute of Technology Delhi, Department of Civil Engineering, Hauz Khas, New Delhi - 110 016, India \\ Received 30 April 2012; accepted 22 August 2012
}

\begin{abstract}
Traffic congestion has been one of major issues that most metropolises are facing. It is believed that identification of congestion is the first step for selecting appropriate mitigation measures. Congestion - both in perception and in reality - impacts the movement of people. Traffic congestion wastes time, energy and causes pollution. There are broadly two factors, which effect the congestion; (a) micro-level factors (b) macro-level factors that relate to overall demand for road use. Congestion is 'triggered' at the 'micro' level (e.g. on the road), and 'driven' at the 'macro' level. The micro level factors are, for example, many people want to move at the same time, too many vehicles for limited road space. On the other side, macro level factors are e.g. land-use patterns, car ownership trends, regional economic dynamics, etc. This paper gives an overview and presents the possible ways to identify and measure metrics for urban arterial congestion. A systematic review is carried out, based on measurement metrics such as speed, travel time/delay and volume and level of service. The review covers distinct aspects like definition; measurement criteria followed by different countries/organizations. The strengths and weaknesses of these measures are discussed. Further, a short critique of measurement criteria is presented.
\end{abstract}

Keywords: traffic congestion, data collection methods, congestion measurement.

\section{Introduction}

Traffic congestion has been one of major issues that most metropolises are facing and thus, many measures have been taken in order to mitigate congestion. It is believed that identification of congestion characteristics is the first step for such efforts since it is an essential guidance for selecting appropriate measures. Congestion - both in perception and in reality - impacts the movement of people and freight and is deeply tied to the history of high levels of accessibility and mobility. Traffic congestion wastes time and energy, causes pollution and stress, decreases productivity and imposes costs on society.

\footnotetext{
${ }^{2}$ Corresponding author: rrkalaga@civil.iitd.ac.in
}

There are two principal categories of causes of congestion, and they are; (a) micro-level factors (e.g. relate to traffic on the road) and macro-level factors that relate to overall demand for road use. Congestion is "triggered" at the "micro" level (e.g. on the road), and "driven" at the "macro" level by factors that contribute to the incidence of congestion and its severity. The micro level factors are, for example, many people and freight want to move at the same time, too many vehicles for limited road space. Many trips may be delayed by events that are irregular, but frequent: accidents, vehicle breakdowns, poorly timed traffic signals, special events like mass social gatherings, political rallies, 
bad weather conditions, etc. which present factors that cause a variety of traffic congestion problems. On the other side, macro level factors e.g. land-use patterns, employment patterns, income levels, car ownership trends, infrastructure investment, regional economic dynamics, etc. also may lead to congestion.

Measures aimed at reducing congestion can be either demand or supply side oriented. It is therefore important to distinguish both types of measures. Three main factors influence the supply side of road travel. Firstly, capacity is one of the most important elements of road space supply. For example, the total kilometres of roads and the number of lanes determine the capacity of the road network. Secondly, the operation of the road network influences supply. Maximising the efficiency of operations, such as optimising signals improves "supply". Thirdly, the supply of the road transport equation is also affected by incidents such as accidents or road works. Importantly, the last two aspects can be influenced by traffic management approaches. It is thus the supply-side of the road network that can be optimised by traffic management tools. Supply of road space is mainly determined by past investment decisions and current operations. Changes in the supply side of road space thus involve construction of new road space or reductions in existing road space. Changes in traffic operations are also considered to be supply side measures.

Demand for road space is influenced by a large number of issues. Essentially, demand is created when the need for travel between an origin and a destination arises. Demand therefore strongly depends on socio-economic and population factors. Another important factor influencing demand is the relative cost of road travel as well as the availability of alternative means of transport. Other aspects that influence demand for road travel are availability of parking and the social perception of car versus public transport travel.

This paper discuses the existing practices in different countries, the contributions by individuals and prevailing methodologies for measurement of the congestion along with the critical review of the methods. Review has also been done with reference to Indian conditions. The critique and the suggested methodology may be useful for similar developing countries.

\section{Existing Practices in Different Countries}

\subsection{United States of America}

The United States have systematic programmes to identify the traffic congestion and to handle the congestion problems. California Department of Transportation (Caltrans): Caltrans defines congestion as occurring on a freeway when the average speed drops below $35 \mathrm{mph}$ for 15 minutes or more on a typical weekday (Varaiya, 2001). In Minnesota, freeway congestion is defined as traffic flowing below $45 \mathrm{~km} / \mathrm{h}$ for any length of time in any direction, between 6:00 a.m. and 9:00 a.m. or 2:00 p.m. and 7:00 p.m. on weekdays (Bertini, 2006). Michigan defines freeway congestion in terms of LOS F, when the volume/ capacity ratio is greater than or equal to one (Bertini, 2006). Denver Regional Council of Governments (DRCOG) examines traffic congestion (DRCOG, 2011) by studying the regional vehicle miles travelled measures and regional freeway bottlenecks time to time and discuss the key reasons for the bottleneck, possible mitigation strategies and congestion measurements. Council monitors various congestion measures like: Vehicle Miles and Hours of Travel, Average Travel Speed (mph), 
Person Miles of Travel (VMT), and Person Hours of Travel, etc. The council's web site is operational and available for public use and review. Web site displays the congested corridor if the speed on the corridor is less than $15 \mathrm{mph}$. The greater Montréal considers the vehicle have joined a highway queue when its speed drops below $25 \mathrm{~km} / \mathrm{h}$ and is considered to have left the queue when its speed rises above the $60 \mathrm{~km} / \mathrm{h}$ mark. Rhode Island State DOT attempts to use objective congestion performance measures such as percent travel under posted speed and volume/capacity ratios (Bertini, 2006).

\subsection{South Korea}

In South Korea there are several agencies involving the operation of traffic flow. Korea Highway Corporation (KHC) identifies traffic congestion spots where vehicle speeds fall below $30 \mathrm{~km} / \mathrm{h}$ or traffic congestion continues longer than 2 hours a day with occurring 10 days a month. Daejoin city ITS center following the congestion criteria at vehicle speed less than $14 \mathrm{~km} / \mathrm{h}$ (Choi et al., 2007).

\subsection{Japan}

Japan uses the speed as threshold value to identify the potential traffic congestion areas. It is said traffic congestion if freeway travel speed falls below $40 \mathrm{~km} / \mathrm{h}$, if there are repeated 'Stop-and-Go' flows for more than $1 \mathrm{~km}$, or if these conditions stay more than 15 minutes.

\subsection{India}

Traffic congestion is a major problem for transportation professionals in India. Most of the cities are suffering from medium to high level of traffic congestion. Although in some major cities the growth of private vehicle usage has increased at a faster rate, in general, car ownership and usage has remained at a much lower level in Indian context. The poor roadway condition, non-uniform roadway features in terms of carriageway and shoulder width, encroachment of road, abutting land use and resulting pedestrian activities, poor lane discipline, improper bus stop location and design, vehicles of wide ranging characteristics of technology and operating condition, heterogeneity of traffic, uncontrolled on-street parking, etc. indicate that the nature and cause of congestion in India might be substantially different from that in the developed countries. Although the roads are becoming at a fast rate, there has been no serious attempt to quantify the growth of congestion in different cities in India. The non-availability of funds for additional roadway infrastructure has seriously constrained the growth of the supply side.

\subsection{Studies Carried Worldwide}

Congestion can be defined as the situation when traffic is moving at speeds below the designed capacity of a roadway (Downs, 2004). Congestion may be defined as state of traffic flow on a transportation facility characterized by high densities and low speeds, relative to some chosen reference state (with low densities and high speeds) (Bovy and Salomon, 2002). Traffic congestion is a condition of traffic delay (when the flow of traffic is slowed below reasonable speeds) because the number of vehicles trying to use the road exceeds the traffic network capacity to handle those (Weisbrod et al., 2001). Traffic congestion is travel time or delay in excess of that normally incurred under light or free-flow travel conditions (Lomax et al., 1997). Levinson and Lomax (1996) discussed desired attributes of a congestion index. Boarnet et al. (1998) identified three issues that must be addressed in measuring congestion. It should (i) reflect the full range of 
highway performance, (ii) be based on widely available data, and (iii) allow comparison across metropolitan areas. Turner (1992) examined indicators of congestion and suggested that measures to quantify the level of congestion should (i) deliver comparable results for various systems with similar congestion level, (ii) accurately reflect the quality of service for any type of system, and (iii) be simple, welldefined and easily understood and interpreted among various users and audiences. Medley and Demetsky (2003) studied how to define the performance measure(s) that could be used to show congestion levels on critical corridors throughout Virginia and to develop a method to select and calculate performance measures to quantify congestion in a transportation system. Total delay and the buffer index were used in the investigation. The methodology is applied for Hampton Roads region of Virginia. Robert and Theodore (2002) discussed various approaches for quantifying congestion and how these different measures affect the perception of the problems. In a study done for the state of New Jersey, thresholds of the volume-capacity ratio on any given roadway were adopted to identify where congestion was occurring. The severity of this congestion was then analyzed by using both distance-based and time-based measures to describe the magnitude of the problems. Stathopoulos and Karlaftis (2002) studied how to estimate the duration of congestion on a given road section and the probability that, given its onset, congestion will end during the following time period. The results indicated that the Log logistic functional form best describes congestion duration. Aworemi et al. (2009) examined the causes/ effects (road condition, accidents etc.) and possible ameliorative measures of road traffic congestion in some selected areas of Lagos State. Choi et al. (2007) conducted a study by applying Travel Time Index (TTI) to show the level of traffic congestion. It was observed that TTI index describes the traffic congestion in both time and space with minimum of data collection effort. Hongsakham et al. (2008) proposed method for estimating degrees of road traffic congestion by using Cell Dwell Time (CDT) information available from cellular networks and classified into degrees of congestion. Dowling et al. (2004) defined a methodology for estimating and predicting the total annual traffic congestion attributable to recurrent and non-recurrent congestion. The methodology is applicable to freeways, conventional highways, and urban streets. Ishida et al. (2003) develop the recording system of the driver's judgment on congestion/jam by using PC to find major factors affecting the congestion/jam recognition of drivers as well as passengers, and lastly to develop congestion/ jam judgment model. A methodology and its application to measure total, recurrent, and non-recurrent (incident related) delay on urban freeways are described using two real-life freeway corridors in Los Angeles, California, and one in the San Francisco, California, Bay Area (Skabardonis et al., 2003). The authors observed that incident-related delay was found to be $13-30 \%$ of the total congestion delay during peak periods. Thurgood (1995) developed an index called Freeway Congestion Index, which simultaneously captures the extent and duration of congestion on freeways. Owusu et al. (2006) demonstrated that efficient vehicle monitoring can be achieved by integrating Global Positioning System (GPS) derived traffic data such as vehicle speed and direction of traffic flow into a Geographical Information System (GIS) environment. The system developed has been used to show the second-to-second positional changes in speed and directions of vehicles travelling in Kumasi, the second largest city in Ghana. The aim of the study performed by Ishizaka et al. (2005) is to discuss the feasibility of a system to collect traffic information using probe vehicles in a developing 
city (Bangkok) in terms of cost efficiency. Study estimated the minimum number of probe vehicles that can ensure sufficient data collecting information from which reliable average travel time can be calculated. The Transport Systems Centre (TSC) has developed an integrated Global Positioning System (GPS) (Taylor et al., 2000). This paper presents a review of issues, procedures, and examples of application of geographic information system (GIS) technology to the development of congestion management systems (CMSs). The paper examines transportation network performance measures and discusses the benefit of using travel time as a robust, easy to understand performance measure. Dewees (1978) use a simulation program to estimate the external time costs that an additional vehicle using a congested city street imposes on other motorists on that street. This study demonstrated the usefulness of a traffic simulation program for estimating congestion costs. The paper addresses data needs and examines the use of global positioning system (GPS) technology for the collection of travel time and speed data. Stathopoulos and Karlaftis (2002) tried to probabilistically model the duration of traffic congestion using log-logistic function. Cottrell (1991) developed logistic regression models with explanatory variables, $\mathrm{AADT} /$ capacity, K-factor (i.e., the ratio of the 30th highest hourly volume of the year to the AADT) to predict the occurrence of congestion. Simulation program is used to estimate the external time costs that an additional vehicle using a congested city street imposes on other motorists on that street. The traffic flow on two street networks in Toronto is simulated for the morning rush hour and a mid-day period. This study demonstrated the usefulness of a traffic simulation program for estimating congestion costs and identifies some problems inherent in previous empirical approaches to this problem.

\subsection{Asian Countries}

Sun et al. (2009) studied the relations between traffic flow parameters of traffic bottleneck and phase transitions in profiles of traffic flow fundamental parameters. Zhengyu et al. (2009) studied the spatiotemporal characteristics of urban traffic congestion, and identified the frequent congested sections in the network of Shanghai city using floating car data. Hao et al. (2008) focus on experimental observations and theoretical analysis of urban freeway congestion due to complex features of traffic flow, shock wave and state transition. Study observed that the theory of shock wave speed could be used to help establishing traffic control strategies and to control queue length. Hao et al. (2007) classify the traffic states and define types of recurrent congestion according to their evolvement. An approach of identifying traffic control area and congestion source using spatial-temporal speed figure is introduced. Pattara-atikom et al. (2006) investigates way to estimate degrees of road traffic congestion based on GPS measurements from main roads in urban areas of Bangkok, Thailand. The study used human perception to obtain classification thresholds and evaluated the performance of the proposed method. Zhang and Gang (2009) studied the system objective function of minimum network congestion - values and the quantitative analysis model of traffic congestion state for the Sioux Falls network. Lam and Tam (1997) investigate why the standard modelling and evaluation procedures currently used by the Hong Kong Government are inadequate for assessing the traffic congestion measures. Empirical evidence is given together with discussion on modelling and evaluation issues raised by the existence of suppressed/induced traffic. 


\subsection{India}

Roy et al. (2011) discuss a novel and interesting way to detect the congestion on the urban arterials in India. They suggest using a Wi-Fi signal emitting device and a receiver across the road to identify the congestion. This method was found to be successful in terms of high accuracy of classifying the road as congested or free flowing. Sen et al. (2009) discussed the characteristics of the ITS techniques that need to be developed to cater the traffic conditions and congestion in developing regions and presented a brief description of a few efforts being made in this direction. Merugu et al. (2009) discuss the project INSTANT (INfosys-STANford Traffic project), carried out for six months from Oct 6, 2008, to April 10, 2009 and which involved about 14,000 employees of Infosys. The aim of the project is providing incentives to decongestors. The project succeeded in incentivizing many commuters to travel at uncongested times, thereby significantly reducing their commute times. Dewan and Ahmad (2007) conducted a survey for car-pooling in Delhi and willingness of commuters for car pooling and they observed that car-pooling is one of the solutions to reduce the traffic congestion in Delhi. Pucher et al. (2005) summarize key trends in India's transport system and travel behaviour, analyze the extent and causes of the most India's urban transport crisis, severe problems, and recommend nine policy improvements that would help mitigate the problems.

\section{Identification of the Congestion Measurement Metrics}

Congestion can generally be defined as excess demand for road travel. Supply of road travel infrastructure is not sufficient to meet demand levels to a given level of service. Consequently, travel speeds fall and delays are explained. This general definition of congestion implies that it can be measured in various ways. Average speed, flow/density, delay and travel time variability can all be used to assess the level of congestion.

\subsection{Speed}

The prevailing traffic speed at any section of a roadway affects the quality of traffic at the time. Whereas excessive speeds affect the severity of road traffic accidents, crawling speeds in the urban environment are also indicative of congestion. Nowadays, efficient vehicle monitoring can be achieved by integrating Global Positioning System (GPS) derived traffic data such as vehicle speed and direction of traffic flow into a Geographical Information System (GIS) environment.

\subsection{Travel Time and Delay}

Congestion is a travel time or delay in excess of the normally incurred under light or free flow travel conditions (Lomax et al., 1997). Unacceptable congestion is travel time or delay in excess of an agreed-upon norm. The agreed-upon norm may vary by type of transportation facility, travel mode, geographic location, and time of the day. The authors of the study conducted using the U.S. Census data to analyze the unacceptable congestion, concluded that the unacceptable congestion is when less than half of the population can commute to work in less than 20 minutes or if more than $10 \%$ of the population can commute to work in more than 60 minutes. The regional council of governments in Tulsa, Oklahoma defines congestion as travel time or delay 
in excess of that normally incurred under light or free-flow travel conditions. Traffic congestion is travel time or delay in excess of that normally incurred under light or freeflow travel conditions (Lomax et al., 1997). Congestion is the presence of delays along a physical pathway due to presence of other users (Kockelman, 2004).

\subsection{Volume}

In Cape Cod, Massachusetts, a traffic congestion indicator is used to track average annual daily bridge crossings over the Sagamore and Bourne bridges. This very simple measure was chosen for this island community since it is appropriate, easy to measure, and since historic data are available to monitor longterm trends. Congestion usually relates to an excess of vehicles on a portion of roadway at a particular time resulting in speeds that are slower sometimes much slower than normal or "free flow" speeds (Cambridge Systematic and TTI, 2005).

\subsection{Level of Service (LOS)}

Michigan defines freeway congestion in terms of LOS F, when the volume/capacity ratio is greater than or equal to one.

\subsection{Demand/Capacity Related}

Congestion prevents traffic from moving freely, quickly and/or predictably (OECD, 2006). When vehicular volume on a transportation facility (street or highway) exceeds the capacity of that facility, the result is a state of congestion (Vuchic and Kikuchi, 1994). Traffic congestion occurs when travel demand exceeds the existing road system capacity (Rosenbloom, 1978). Congestion is a condition in which the number of vehicles attempting to use a roadway at any time exceeds the ability of the roadway to carry the load at generally acceptable service levels (Rothenberg, 1985). Congestion is an imbalance between traffic flow and capacity that causes increased travel time, cost and modification of behaviour. Congestion is a condition that arises because more people wish to travel at a given time than the transportation system can accommodate: a simple case of demand exceeding supply (Miller and Li, 1994). Congestion is the impedance vehicles impose on each other, due to the speed-flow relationship, in conditions where the use of a transport system approaches its capacity (ECMT, 1999).

\subsection{Cost Related}

Congestion is undesirable as it reduces accessibility and increases costs associated with travel. The level of access is determined by various factors including travel time and reliability. As congestion affects travel time and reliability, it reduces accessibility. Traffic congestion refers to the incremental costs resulting from interference among road users (VTPI, 2005).

\subsection{Others}

In the State of Oregon, the 1991 Transportation Planning Rule (TPR, 1991) uses VKT (Vehicle Kilometers Traveled) as a primary metric, with a goal of reducing VKT by $20 \%$ per capita in metropolitan areas by 2025 . Congestion may be defined as state of traffic flow on a transportation facility characterized by high densities and low speeds, relative to some chosen reference state (with low densities and high speeds) (Bovy and Salomon, 2002).

\section{Congestion Measurement Methodologies and Inconsistencies}

Congestion measurement methodology should have the following characteristics: (a) It should 
be simple to understand and unambiguous; (b) It should have the ability to describe the existing traffic conditions and predict the future changes; (c) It should have an ability to apply statistical techniques, replicability of the results with a minimum of data collection; (d) The methodology should have applicability to various modes, facilities and time periods.

\subsection{Speed}

The literature has suggested several speed measures besides average travel speed. The average travel rate, in minutes per mile, is the reciprocal of average travel speed. Peak period nominal speeds are a weighted average of speeds on freeways and principal arterial streets, which allow comparison of the freeway and principal arterial street network between urban areas. The ratio of peak period to off-peak period speed suggested as direct measures of congestion. Some of the approaches based on speed are described below.

\subsubsection{Empirical Relationships}

Several of the early efforts in congestion measurement centred on empirical relationships that attempted to incorporate driver effort and satisfaction into an index of the quality of traffic flow. The quality of traffic transmission index ( $Q$ index) was defined as a function of average speed and the number and sum of speed changes (Eq. (1)) (Levinson and Lomax, 1996).

$\mathrm{Q}=\mathrm{KS} /\left(\Delta_{\mathrm{s}} \sqrt{\mathrm{f}}\right)$

Where:

Q - quality of traffic transmission index,

$\mathrm{K}=1000$ - constant,

$S$ - average speed (mph),

$\Delta_{\mathrm{s}}$ - absolute of speed changes per mile, and

$\mathrm{f}$ - number of speed changes per mile.

\subsubsection{Corridor Mobility Index}

Corridor Mobility Index (CMI) is a measure of the person-carrying capacity of corridors (Lomax et al., 1997). The speed of person volume is the product of travel speed and peak-hour person volume per lane. CMI or rate of person movements has been defined as the product of peak-hour vehicle occupancy and travel speed.

\subsubsection{Speed Reduction Index}

This measure represents the ratio of the decline in speeds from free flow conditions. It provides a way to compare the amount of congestion on different transportation facilities by using a continuous scale to differentiate between different levels of congestion. The index can be applied to entire routes, entire urban areas, or individual freeway segments for off-peak and peak conditions.

\section{Critique:}

Congestion is a function of a reduction in speeds, which is the direct cause of loss of time and leads to increased vehicle operating costs, fuel consumption, and emissions of air pollutants and Green House Gases (GHGs). Therefore, the setting of a threshold that is directly related to travel speeds is most appropriate. This is in contrast to the traditional planning use of LOS, which compares volumes with capacity and does not explicitly account for speed. A speed-based threshold account for more of the impacts of congestion than would a threshold based on capacity.

The use of a range of speed for entire study area reflects the lack of consensus among urban areas as to the appropriate threshold, which reflects local conditions. Speed reduction index measure may be difficult for public to 
understand because result is a number with no units. Result is relative to free flow speed, which is difficult for motorists to comprehend.

\subsection{Travel Time}

The use of travel time studies (Lomax et al., 1997) and related measures to describe system performance and congestion permeated the traffic engineering literature as early as the late 1920s. The early studies concentrated on determining average travel speeds in congested downtown areas and attempted to locate the magnitude and sources of travel delay. Some of the indices related to travel time are listed below.

\subsubsection{Travel Time Index (TTI)}

Travel Time Index was proposed in the Urban Mobility Report (Schrank and Lomax, 2005). Index compares peak period travel and free flow travel while accounting for both recurring and incident conditions. This index is expressed by comparing travel time in free flow condition and the one in peak hours. Index has the advantage of expressing traffic congestion in terms of both space and time, Eq. (2):

$T T I=\frac{\text { PeakPeriodTravelTime }}{\text { FreeFlowTravelTime }}=\frac{\text { FreeFlowTravelSpeed }}{\text { PeakPeriodTravelSpeed }}$

\subsubsection{Travel Rate Index (TRI)}

This index computes the "amount of additional time that is required to make a trip because of congested conditions on the roadway." It examines how fast a trip can occur during the peak period by focusing on time rather than speed (Levinson and Lomax, 1996). The TRI is an indicator for entire portions of the analysed network based on the respective distance and number of vehicles supported by each section.

\subsubsection{Buffer Index}

The buffer index calculates the extra percentage of travel time a traveller should allow when making a trip in order to be on time $95 \%$ of the time. This method uses the 95th percentile travel rate and the average travel rate, rather than average travel time, to address trip concerns. The buffer index represents the reliability of travel rates associated with single vehicle. This measure may be beneficial to the public because it tells them how congestion will affect them as individuals.

In addition to above, there are few more indices like Misery Index, Travel rate, Congested travel, Congested roadway, Accessibility, Congestion Index also available based on the travel time in the literature.

\section{Critique:}

Time-based congestion measures provide a different perception on congestion, one in keeping with the common perception of the problem. Time-based congestion measures also provide guidance on identifying major issues, enabling policy makers to better address problems within the state and solutions that are most likely to have the greatest impact. Travel time index has the advantage of expressing traffic congestion in terms of both space and time. It is easy for public to understand the main concept of this index.

The time-based measures of congestion provided a stronger basis for more generalized conclusions. Travel time index requires separation of recurring and incident delay. Measurement of non-recurring data can be difficult. Travel Rate Index does not comprise the finer traffic events; it is not responsive to exceptional conditions 
related to climatic events, accidents or construction activity interferences. Travel Rate Index measure can be difficult for public to understand.

\subsection{Level of Service}

Traditionally, the use of level of service (LOS) has been one of the most popular measures of traffic congestion. The LOS concept as adopted in the HCM (1985) represents a range of operating conditions. Volume to capacity ratio can provide a good measure of the volume compared to capacity of the roadway under existing and future conditions. Therefore, volume-tocapacity can be used as a measure of future performance through basic calculations using available data. Where accurate future land use data is available, growth can be estimated based on anticipated development activity versus anticipated growth rates. Volume to capacity ratios could be compared to LOS to reach conclusions about congested conditions. Some of the congestion indexes, which works based on level of service, are explained below.

\subsubsection{Roadway Congestion Index}

The roadway congestion index ( $\mathrm{RCI}$ ), developed by Shrank and Lomax (2005), a measure of the daily Vehicle Mile Travel (VMT) per lane-mile of freeways and principal arterial streets, is an empirically derived formula to quantify the relative congestion levels in urban areas. This index allows for comparison across metropolitan areas by measuring the full range of system performance by focusing on the physical capacity of the roadway in terms of vehicles (Eq. (3)).

\subsubsection{Lane-Mile Duration Index}

The lane-mile duration index (LMDI), a measure of the extent and duration of freeway congestion, was developed by Cottrell (1991) in a study of congestion in 35 urban areas. The LMDI value for each urban area is the sum of the product of congested freeway lane-miles and congestion duration (hours) for individual roadway segments, and is calculated using the indicator of average annual daily traffic volume per hourly capacity $(\mathrm{AADT} / \mathrm{C})$. The methodology assumed a $\mathrm{v} / \mathrm{c}$ ratio greater than 1.0 (LOS F), or $\mathrm{AADT} / \mathrm{C}$ ratio greater than 9.0, to represent congested travel conditions (Eq. (4)).

$$
\mathrm{RCI}=\frac{\left[\text { Freeway } \frac{\mathrm{DVMT}}{\mathrm{Ln}} .-\mathrm{Mi} . * \text { Fwy } . \mathrm{DVMT}\right]+\left[\text { Prin.Art } . \frac{\mathrm{DVMT}}{\mathrm{Ln}} .-\mathrm{Mi} . * \operatorname{Prin} . \text { Art } . \mathrm{DVMT}\right]}{[13,000 * \text { Fwy } . \mathrm{DVMT}]+[5,000 * \text { Prin } . \text { Art } . \mathrm{DVMT}]}
$$

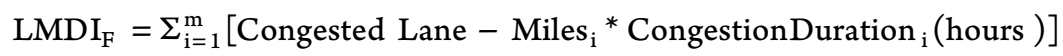

Where i equal to an individual freeway segments and $\mathrm{m}$ equals the total number of freeway segments in an urban area. 


\section{Critique:}

The main advantage of LOS measure is that it is comprehensible by most non-technical audiences. This is the representative variable in traffic flow analysis. It is widely used because it is very easy to collect this data in the field.

LOS cannot provide a continuous range of values of congestion and these methods provide no distinction between different levels of congestion once congested conditions are reached. Byrne and Mulhall (1995) criticized level of service analysis a measure of congestion because it only represents location-specific congestion phenomenon and does not reflect overall or regional congestion condition. Hamad and Kikuchi (2002) have argued that the use of a stepwise LOS measure is sometimes misleading, especially when the condition is near a threshold. Lane-Mile Duration Index has a limitation that it can't reflect the effect of having different highway functions on traffic congestion. Lane-mile duration index results would be poor since not all freeway segments in area collect traffic data.

\subsection{Delay Measures}

Delay has been defined as the additional time experienced by a road user in comparison to the free flow travel or the acceptable travel time. For delay estimation, researchers have used different threshold values for the beginning of delay. Lindley (1987) used a threshold of congestion to begin at a volume to capacity $(\mathrm{v} / \mathrm{c}$ ) ratio of 0,77 (or the speed of $55 \mathrm{mph}$ corresponding to $\mathrm{v} / \mathrm{c}$ ratio of 0,77 ). Lomax et al. (1997) used certain specified values for different roadway categories based on consensus among technical and nontechnical groups to determine acceptable travel time and threshold for the beginning of congestion. Schrank and Lomax (2005) used $60 \mathrm{mph}$ for freeways and $35 \mathrm{mph}$ for arterial roads as free flow speed for comparison with congested speeds and they used the 85 th percentile speed in the off-peak period as the free flow speed.

\section{Critique:}

Delay rate can be used to estimate the difference between system performance and the expectations for those system elements, which can be used to rank alternative improvements (Lomax et al., 1997). Relative delay rate reflects the condition of flow that travellers' can relate to their travel experience (Hamad and Kikuchi, 2002). Total delay could also allow transportation professionals to estimate how improvements within a transportation system affect a particular corridor or the entire system. Total delay shows the effect of congestion in terms of the amount of lost travel time.

The use of ratio measures is limited for a particular road type or facility and the value cannot be used effectively for a geographic area. Relative delay rate measure may be difficult for public to understand because result is a number with no units. Congested travel or congested roadway length does not represent the different magnitude of congestion.

\section{Data Collection Methods}

Data collection techniques can be broadly classified into two categories, one-probe vehicles (mobile vehicles with data collection equipment), and others that are making use of fixed sensors. The traffic congestion studies data can be collected by both methods, point's data like traffic volume count, speed etc., using fixed sensors and travel time, journey speed etc., using probe vehicles data like floating car method. 


\subsection{Fixed Sensor Based Techniques}

These techniques include sensors such as inductive loop detectors, magnetic sensors, etc. that are deployed on road to collect the required data. Some of the fixed sensor techniques are described below.

\subsection{Dual Loop Detector Based Techniques}

Pairs of inductive loop detectors placed at various locations on the road can be used to identify vehicles on the basis of axle spacing (Benjamin and Cassidy, 2002). This type of data used to measure travel time of vehicles between the detector stations. This data can be used to inference/estimate the traffic congestion.

\section{Critique:}

Widespread application of the technique in congestion detection can be prohibitive in terms of infrastructure cost, as dual loop detectors need to be constructed at regular intervals along the road. This technique is costly and the algorithm in Benjamin and Cassidy (2002) assumes that consecutive vehicles often maintain their relative order within a platoon for long distances. In India, the axle spacing for truck and buses are same, hence classification of the vehicle are not accurate. This lane-based system assumption is unrealistic in Indian traffic scenarios where overtaking, buses and auto-rickshaws stopping to pick up or drop off passengers is common phenomena.

\subsection{Magnetic Sensor Based Technologies}

Cheung et al. (2004) has suggested magnetic sensor as a low-cost alternative of inductive loops. It primarily performs vehicle identification and classification using a single magnetic sensor. Vehicle identification is further used to detect congestion by extracting information like speed and length of the vehicle.

\section{Critique:}

Experiments have been performed on a road with intersection that follows a lane system. This assumption makes this method unfit for Indian traffic as discussed above. Absence of a lane based system implies that vehicles need not approach the sensor in a way which will assure their detection. Studies show (Cheung et al., 2004) that the motorcycle detection is not reliable. This is a concern because a large percentage of Indian traffic consists of two-wheelers.

\subsection{Image Sensor Based Techniques}

Some of the studies (Palubinskas et al., 2008; Long Chen et al., 2008) make use of image sensors like CCTV, deployed on the road side and measure congestion level by image processing techniques, where slower the images change with time, higher is the level of congestion. Similar techniques (Hinz et al., 2007) have been used to process satellite images.

\section{Critique:}

These are more costly systems than loop detector techniques and also require high maintenance cost, which makes it prohibitive to deploy these in India. Proper positioning and distribution of cameras to capture images of disorderly traffic will be a challenging factor. Frame level change detection algorithms need to be modified for Indian roads so that image change due to extraneous factors like people crossing road through cars stuck at congestion should be filtered out and not incorrectly interpreted as free flowing traffic.

\subsection{Probe Vehicle Based Techniques}

Probe vehicles are vehicles that are part of traffic and equipped with various sensors 
like GPS receiver, accelerometer, Distance Measuring instruments (DMI), etc. to measure various parameters such as speed with which traffic is moving, road surface condition, etc. Probe vehicle based techniques are classified below into two categories, based on: i) prediction techniques, and ii) localization techniques.

\section{Congestion prediction:}

The data collected by this technique will be used for characterizing traffic by segmenting the road, delimited by traffic signals. A segment is part of road for which vehicles exhibit similar speed because they are subjected to same fundamental conditions like the same traffic signal, road length, width and number of lanes. Average, temporal and spatial speeds, calculated from GPS data, are used for characterizing traffic as free flowing or congested.

\section{Critique:}

Segments are bounded by signalized intersections. In India, even within such a segment, traffic conditions will vary as there will be many intermediate intersections, unsignalized, where drivers will follow random protocols to decide who will go first.

The techniques discussed above form a representative set of the broad categories of data collection techniques used for traffic sensing. As pointed out, each of them has some associated drawbacks that prevent it from being applicable as it is on Indian roads. The probe vehicle technique might be used in India after proper evaluation and the data collected by this technique should be validated on sample basis by conventional method used in Indian. Rao and Rao (2009) evaluated a methodology for applying the GPS for measurement of travel time and speed and validated the results with conventional methods and also carried out the statistical checks, the results obtained by GPS are satisfactory and can be used for measurement of traffic congestion studies.

The advantages and limitations of various methods have been listed in Table 1. This table clearly brings out how the macro level measurement indices. Further, there are five criteria of evaluation of a particular macro level metric that is given and this is shown in Table 2. It is evident that the stream speed is the one that satisfies the set criteria and thus it can be chosen as the most suitable congestion index. This is however not to discount on the other indices, but their preference priority would be below the stream speed.

From Table 2 it is clear that any congestion metric does not fulfil all of the assessment criteria, but the speed related measures fulfil the most of the criteria (Aftabuzzaman, 2007), after selecting the measurement metrics, next activity is preparation of data collection matrix which covers holidays, working days, all peak hours to capture all the traffic characteristics. Sufficient data collection should be collected for sample sections, these data can be analyzed to define the congestion threshold on this metrics and development of congestion index for assessing the intensity of congestion. Finally, development of congestion mitigation strategies and studying the strategies using the micro simulation models and suggesting the solutions which are feasible for local conditions is discussed.

\section{Summary and Outlook}

A range of features have been suggested for a measure of congestion. The measures to quantify the level of congestion should, 


\section{Table 1}

\section{Comparison of Macro Level Congestion Indices}

\begin{tabular}{|c|c|c|}
\hline Macro Level Indices & Advantages & Limitations \\
\hline Travel time and delay & $\begin{array}{l}\text { Time-based congestion measures } \\
\text { provide guidance on identify- } \\
\text { ing major issues, enabling policy } \\
\text { makers to better address problems } \\
\text { within the state and solutions that } \\
\text { are most likely to have the greatest } \\
\text { impact. } \\
\text { Travel time index has the } \\
\text { advantage of expressing traffic } \\
\text { congestion in terms of both space } \\
\text { and time. } \\
\text { It is easy for public to understand } \\
\text { the main concept of this index. }\end{array}$ & $\begin{array}{l}\text { The time-based measures of congestion provided a } \\
\text { stronger basis for more generalized conclusions. } \\
\text { Travel time measures do not comprise the finer } \\
\text { traffic events; it is not responsive to exceptional } \\
\text { conditions related to climatic events, accidents or } \\
\text { construction activity interferences. } \\
\text { Total delay could also allow transportation profes- } \\
\text { sionals to estimate how improvements within a } \\
\text { transportation system affect a particular corridor } \\
\text { or the entire system. } \\
\text { The use of ratio measures is limited for a particular } \\
\text { road type or facility and the value cannot be used } \\
\text { effectively for a geographic area. } \\
\text { Congested travel or congested roadway length } \\
\text { does not represent the different magnitude of } \\
\text { congestion. } \\
\text { Travel time index requires separation of recurring } \\
\text { and incident delay. Measurement of non recurring } \\
\text { data can be difficult. } \\
\text { The use of ratio measures is limited for a particular } \\
\text { road type or facility and the value cannot be used } \\
\text { effectively for a geographic area. } \\
\text { Congested travel or congested roadway length } \\
\text { does not represent the different magnitude of } \\
\text { congestion. }\end{array}$ \\
\hline Volume and LOS & $\begin{array}{l}\text { The main advantage of LOS mea- } \\
\text { sure is that it is comprehensible by } \\
\text { most non-technical audiences. } \\
\text { This is the representative variable } \\
\text { in traffic flow analysis. } \\
\text { It is widely used because it is very } \\
\text { easy to collect this data in the field. }\end{array}$ & $\begin{array}{l}\text { LOS cannot provide a continuous range of values } \\
\text { of congestion and these methods provide no } \\
\text { distinction between different levels of congestion } \\
\text { once congested conditions are reached. } \\
\text { Byrne and Mulhall (1995) criticized level of } \\
\text { service analysis a measure of congestion because it } \\
\text { only represents location-specific congestion phe- } \\
\text { nomenon and does not reflect overall or regional } \\
\text { congestion condition. } \\
\text { Hamad and Kikuchi (2002) have argued that } \\
\text { the use of a stepwise LOS measure is sometimes } \\
\text { misleading, especially when the condition is near } \\
\text { a threshold. } \\
\text { Lane-Mile Duration Index has a limitation that it } \\
\text { can't reflect the effect of having different highway } \\
\text { functions on traffic congestion. }\end{array}$ \\
\hline
\end{tabular}




\begin{tabular}{|c|c|c|}
\hline Speed & 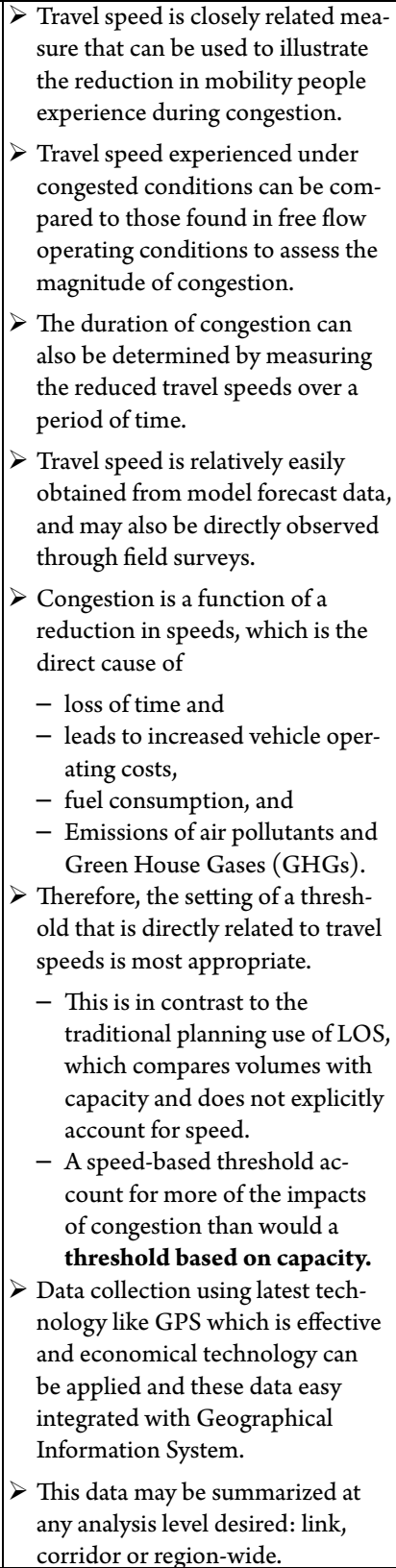 & $\begin{array}{l}\text { The use of a range of speed for entire study area } \\
\text { reflects the lack of consensus among urban areas as } \\
\text { to the appropriate threshold, which reflects local } \\
\text { conditions. } \\
\text { Result is relative to free flow speed, which is dif- } \\
\text { ficult for motorists to comprehend. }\end{array}$ \\
\hline
\end{tabular}




\section{Table 2}

Congestion Indices Evaluation Matrix

\begin{tabular}{|c|c|c|c|c|c|c|c|}
\hline Congestion Metric & 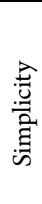 & 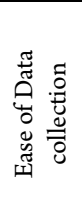 & 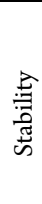 & 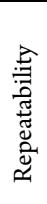 & 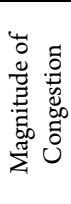 & 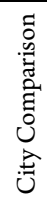 & 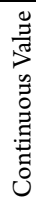 \\
\hline Speed & $\mathrm{Y}$ & $\mathrm{Y}$ & $\mathrm{Y}$ & $\mathrm{Y}$ & $\mathrm{Y}$ & $\mathrm{N}$ & $\mathrm{Y}$ \\
\hline Travel Time & $\mathrm{Y}$ & $\mathrm{Y}$ & $\mathrm{Y}$ & $\mathrm{Y}$ & $\mathrm{N}$ & $\mathrm{N}$ & $\mathrm{Y}$ \\
\hline Delay & $\mathrm{N}$ & $\mathrm{N}$ & $\mathrm{N}$ & $\mathrm{Y}$ & $\mathrm{N}$ & $\mathrm{N}$ & $\mathrm{Y}$ \\
\hline LOS and Volume & $\mathrm{Y}$ & $\mathrm{Y}$ & $\mathrm{N}$ & $\mathrm{Y}$ & $\mathrm{N}$ & $\mathrm{N}$ & $\mathrm{Y}$ \\
\hline
\end{tabular}

(i) Deliver comparable results with similar congestion level, (ii) Accurately reflect the quality of service (iii) Be simple, well-defined and easily understood and interpreted among various users. Considering the different desirable attributes for a congestion measure suggested by the afore-mentioned researchers, congestion is a function of a reduction in speeds, which is the direct cause of loss of time and leads to increased vehicle operating costs, fuel consumption, and emissions of air pollutants and Green House Gases (GHGs). Therefore, the setting of a threshold that is directly related to travel speeds is most appropriate. This is in contrast to the traditional planning use of LOS, which compares volumes with capacity and does not explicitly account for speed. A speed-based threshold account for more of the impacts of congestion than would a threshold based on capacity. Congestion measurement criteria based on speed can be adopted, because traffic speed is highly sensitive parameter and directly related to the vehicle operating cost; safety of the road users. This parameter can be easily measured by various low cost technologies which are highly suitable for Indian conditions.

\section{Acknowledgements}

One of the authors (Amudapuram Mohan Rao) wishes to thank Dr. S. Gangopadhyay,
Director of the Central Road Research Institute, New Delhi, India, for his permission to publish this paper.

\section{References}

Aftabuzzaman, M. 2007. Measuring Traffic Congestion - A Critical Review. In Proceedings of the $30^{\text {th }}$ Australasian Transport Research Forum. 16 p.

Aworemi, J.R.; Abdul-Azeez, I.A.; Oyedokun, A.J.; Adewoye, J.O. 2009. A study of the causes, effects and ameliorative measures of road traffic congestion in Lagos metropolis, European Journal of Social Sciences, 11(1): 119-128.

Benjamin, C.; Cassidy, M. 2002. Vehicle re-identification and travel time measurement on congested freeways, Transportation Research Part A: Policy and Practice. DOI: http://dx.doi.org/10.1016/S0965-8564(01)00046-5, 36(10): 899-917.

Bertini, R.L. 2006. You are the Traffic Jam: An Examination of Congestion Measures [CD]. In $85^{\text {th }}$ Annual Meeting of the Transportation Research Board. 17 p.

Boarnet, M.G.; Kim, E.J.; Parkany, E. 1998. Measuring traffic congestion, Transportation Research Record: Journal of the Transportation Research Board. DOI: http://dx.doi. org/10.3141/1634-12, 1634: 93-99. 
Bovy, P.H.L.; Salomon, I. 2002. Congestion in Europe: measurements, patterns and policies. In Monograph Travel Behaviour: spatial patterns, congestion and modelling. 143-179.

Byrne, G.E.; Mulhall, S.M. 1995. Congestion management data requirement and comparisons, Transportation Research Record: Journal of the Transportation Research Board, 1499: 28-36.

Cambridge Systematics Inc.; Texas Transportation Institute (TTI). 2005. Traffic Congestion and Reliability: Trends and Advanced Strategies for Congestion Mitigation. Washington, D. C.: Federal Highway Administration. 140 p.

Cheung, S.Y.; Coleri, S.; Dundar, B.; Ganesh, S.; Tan, C-W.; Varaiya, P. 2004. Traffic measurement and vehicle classification with a single magnetic sensor. Available from Internet: <http://paleale.eecs.berkeley.edu/ varaiya/ papers_ps.dir/sensors_trb_final4.pdf $>$.

Choi, J.; Lee, C.; Lee, S.; Yu, J. 2007. Development of the Traffic Congestion Index for Freeway Corridors in South Korea. In Proceedings of the 7th International Conference of Eastern Asia Society for Transportation Studies 2007.

Cottrell, W.D. 1991. Measurement of the extent and duration of traffic congestion in urban areas. In Proceedings of the 61st Annual Meeting, Istitute of Transportation Engineers. 427-432.

Dewan, K.K.; Ahmad, I. 2007. Carpooling: A Step to Reduce Congestion (A Case Study of Delhi), Engineering Letters, 14(1): 61-66.

Dewees, D.N. 1978. Simulation of Traffic Congestion in Toronto, Transportation Research. DOI: http://dx.doi. org/10.1016/0041-1647(78)90118-1, 12(3): 153-161.

Dowling, R.; Skabardonis, A.; Carroll, M.; Wang, Z. 2004. Methodology for Measuring Recurrent and Nonrecurrent Traffic Congestion, Transportation Research Record: Journal of the Transportation Research Board. DOI: http://dx.doi. org/10.3141/1867-08, 1867: 60-68.
Downs, A. 2004. Still stuck in traffic: coping with peakhour traffic congestion. Washington, D.C.: The Brookings Institution. $455 \mathrm{p}$.

DRCOG. 2011. Annual Report (2010) on Traffic Congestion in the Denver Region. Available from Internet: <http://www.drcog.org/agendas/2010\%20Annual\%20 Report\%205-5.pdf>.

ECMT. 1999. The spread of congestion in Europe. Paris: OECD Publication Service. 237 p.

Hamad, K.; Kikuchi, S. 2002. Developing a Measure of Traffic Congestion: Fuzzy Inference Approach, Transportation Research Record: Journal of the Transportation Research Board. DOI: http://dx.doi.org/10.3141/180210, 1802: 77-85.

Hao, Y.; Tian-dong, X.; Li-jun, S. 2007. Analysis and control of recurrent traffic congestion on urban expressway. In Proceedings of the 1st International Conference on Transportation Engineering, Southwest Jiaotong University, Chengdu, China. DOI: http://dx.doi.org/10.1061/40932(246)102.

Hao, Y.; Wang, W.; Sun, L.; Xu, T.D. 2008. Research on spatial-temporal features of urban freeway congestion. In Proceedings of the 1st International Symposium on Transportation and Development Innovative Best Practices, Beijing, China. DOI: http://dx.doi.org/10.1061/40961(319)31.

HCM. 1985. Highway Capacity Manual. Washington, D.C.: TRB, National Research Council.

Hinz, S.; Meyer, F.; Eineder, M.; Bamler, M. 2007. Traffic monitoring with spaceborne SAR-theory, simulations, and experiments, Computer Vision and Image Understanding. DOI: http://dx.doi.org/10.1016/j.cviu.2006.09.008, 106(2-3): 231-244.

Hongsakham, W.; Pattara-atikom, W.; Peachavanish, R. 2008. Estimating road traffic congestion from cellular handoff information using cell-based neural networks and k-means clustering. In Proceedings of the 5th International Conference on Electrical Engineering/Electronics, Computer, 
Telecommunications and Information Technology. DOI: http:// dx.doi.org/10.1109/ECTICON.2008.4600361. 13-16.

Ishida, H.; Furuya, H.; Kai, S.H; Okamoto, S. 2003. Travel speed and traffic congestions recognition on expressways, Journal of the Eastern Asia Society for Transportation Studies, 5: 1881-1892.

Ishizaka, T.; Fukuda, A.; Narupiti, S. 2005. Evaluation of probe vehicle system by using micro simulation model and cost analysis, Journal of the Eastern Asia Society for Transportation Studies, 6: 2502-2514.

Kockelman, K. 2004. Traffic congestion. In Monograph Handbook of transportation engineering. $32 \mathrm{p}$.

Lam, W.H.K.; Tam, M.L. 1997. Why standard modelling and evaluation procedures are inadequate for assessing traffic congestion measures, Transport Policy. DOI: http:// dx.doi.org/10.1016/S0967-070X(97)00023-1, 4(4): 217-223.

Levinson, H.S; Lomax, T. 1996. Development of travel time congestion index, Transportation Research Record: Journal of the Transportation Research Board. DOI: http://dx.doi. org/10.3141/1564-01, 1564: 1-10.

Lindley,J.A. 1987. Urban freeway congestion: quantification of the problem and effectiveness of potential solutions, Institute of Transportation Engineers Journal, 57(1): 27-32.

Lomax, S.T.T.; Turner, S.; Shunk, G.; Levinson, H.S.; Pratt, R.H.; Bay, P.N.; Douglas, G.B. 1997. Quantifying congestion, Volume 1, NCHRP Final Report 398. Washington, D.C.: Transportation Research Board. 108 p.

Long Chen, L.L.; Huang, X.; Huang, J. 2008. A traffic congestion estimation approach from video using timespatial imagery. In Proceedings of the First International Conference on Intelligent Networks and Intelligent Systems. DOI: http://dx.doi.org/10.1109/ICINIS.2008.182, 465-469.

Medley, S.B.; Demetsky, M.J. 2003. Development of Congestion Performance Measures Using Its Information, Final
Report. Charlottesville: Virginia Transportation Research Council. 43 p.

Merugu, D.; Prabhakar, B.; Rama, N.S. 2009. An incentive mechanism for decongesting the roads: a pilot program in Bangalore. In Proceedings of the NetEcon '09, ACM Workshop on the Economics of Networked Systems. 6 p.

Miller, M.A.; Li, K. 1994. An investigation of the costs of roadway traffic congestion: a preparatory step for IVHS benefits' evaluation. Berkley: Institute of Transport Studies, University of California. $53 \mathrm{p}$.

OECD. 2006. Managing Urban Traffic Congestion, OECD report. Available from Internet: <http://www. internationaltransportforum.org/Pub/pdf/07Congestion.pdf $>$.

Owusu, J.; Afukaar, F.; Prah, B.E.K. 2006. Towards Improving Road Traffic Data Collection: The Use of GPS/ GIS. In Procedeengs of the Sth FIG Regional Conference Accra. $11 \mathrm{p}$.

Palubinskas, G.; Kurz, F.; Reinartz, P. 2008. Detection of traffic congestion in optical remote sensing imagery. In Procedeengs of the IEEE International Geoscience and Remote Sensing Symposium. DOI: http://dx.doi.org/10.1109/ IGARSS.2008.4779019, 2: II-426-II-429.

Pattara-atikom, W.; Pongpaibool, P.; Thajchayapong, S. 2006. Estimating Road Traffic Congestion Using vehicle Velocity. In Proceedings of the 6th Intertional Conference on ITS Telecommunications. DOI: http://dx.doi.org/10.1109/ ITST.2006.288722, 1001-1004.

Pucher, J.; Korattyswaropam, N.; Mittal, N.; Ittyerah, N. 2005. Urban transport crisis in India, Transport Policy. DOI: http://dx.doi.org/10.1016/j.tranpol.2005.02.008, 12(3): 185-198.

Rao, K.R.; Rao, A.M. 2009. Application of GPS for Traffic Studies, Indian Urban Transport Journal, 8(1): 44-55.

Robert, R.J.A.; Theodore, F.E. 2002. Contrasting timebased and distance-based measures for quantifying traffic congestion levels, Transportation Research Record: Journal 
of the Transportation Research Board. DOI: http://dx.doi. org/10.3141/1817-18, 1817: 143-148.

Rosenbloom, S. 1978. Peak-period traffic congestion: a state-of-art analysis and evaluation of effective solution, Transportation, 7(2): 167-191.

Rothenberg, M.J. 1985. Urban congestion in the United States-what does the future hold, Institute of Transportation Engineers Journal, 55(7): 22-39.

Roy, S.; Sen, R.; Kulkarni, S.; Kulkarni, P.; Raman, B.; Singh, L. 2011. Wireless Across Road: RF based Road Traffic Congestion Detection. In Proceedings of the 5th Annual Worshop on Wireless Systems: Advanced Research and Development. DOI: http://dx.doi.org/10.1109/ COMSNETS.2011.5716525, 1-6.

Schrank, D.; Lomax, T. 2005. The 2005 Annual Urban Mobility Report. Texas: Texas Transportation Institute. 91 p.

Sen, R.; Sevani, S.; Sharma, P.; Koradia, Z.; Raman, B. 2009. Challenges in communication assisted road transportation systems for developing regions. In Proceedings of the 3rd ACM Workshop on Networked Systems for Developing Regions. 6 p.

Skabardonis, A.; Varaiya, P.; Petty, K.F. 2003. Measuring recurrent and non-recurrent traffic congestion, Transportation Research Record: Journal of the Transportation Research Board. DOI: http://dx.doi.org/10.3141/1856-12, 1856: 118-124.

Stathopoulos, A.; Karlaftis, M.G. 2002. Modeling Duration of Urban Traffic Congestion, Journal of Transportation Engineering. DOI: http://dx.doi. org/10.1061/(ASCE)0733-947X(2002)128:6(587), 128(6): 587-590.

Sun, W.; Zhengyu, D.; Xue, Y. 2009. Experimental Features of Urban Freeway Traffic Flow. In Proceedings of the International Conference on Transportation Engineering. DOI: http://dx.doi.org/10.1061/41039(345)592, 3590-3595.
Taylor, M.A.P.; Woolley, J.E.; Zito, R. 2000. Integration of the global positioning system and geographical information systems for traffic congestion studies, Transportation Research Part C: Emerging Technologies. DOI: http://dx.doi. org/10.1016/S0968-090X(00)00015-2, 8(1-6): 257-285.

Thurgood, G.S. 1995. Development of freeway congestion index using an instrumented vehicle, Transportation Research Record: Journal of the Transportation Research Board, 1494: 21-29.

Transportation Planning Rule (TPR) Oregon. 1991. Statewide Congestion Overview for Oregon. Available from Internet: <http://cms.oregon.gov/ODOT/TD/ $\mathrm{TP} /$ docs/cm_hers/overview0204.pdf $>$.

Turner, S.M. 1992. Examination of indicators of congestion level, Transportation Research Record: Journal of the Transportation Research Board, 1360: 150-157.

Varaiya, P. 2001. Freeway Performance Measurement System: Final Report. Available from Internet: <http://www.path.berkeley.edu/PATH/Publications/ PDF/PWP/2001/PWP-2001-01.pdf >.

Victoria Transport Policy Institute (VTPI). 2005. Congestion reduction strategies: identifying and evaluating strategies to reduce congestion. Available from Internet: <http://www.vtpi.org/tdm/tdm96.htm>.

Vuchic, V.R.; Kikuchi, S. 1994. The bus transit system: its underutilized potential, Report DOT-T-94-29, Washington, D.C.: Federal Transit Administration. 82 p.

Weisbrod, G.; Vary, D.; Treyz, G. 2001. Economic Implications of congestion, NCHRP Report 463. Washington, D.C.: Transportation Research Board. 47 p.

Zhang, S.; Gang, R. 2009. Quantitative Analysis Model of Urban Traffic Congestion State. In Proceedings of the 2 nd International Conference on Transportation Engineering. DOI: http://dx.doi.org/10.1061/41039(345)174, 1051-1056.

Zhengyu, D.; Liu, L; Sun, W. 2009. Traffic Congestion Analysis of Shanghai Road Network Based On Floating 
Car Data. In Proceedings of the 2nd International Conference on Transportation Engineering. DOI: http://dx.doi. org/10.1061/41039(345)450, 2731-2736.

\section{MERENJE SAOBRAĆAJNOG ZAGUŠENJA U GRADSKIM PODRUČJIMA - PREGLED}

\section{Amudapuram Mohan Rao, Kalaga Ramachandra Rao}

Sažetak: Saobraćajno zagušenje je jedan od glavnih problema sa kojima se većina metropola suočava. Smatra se da je prepoznavanje ovog problema prvi korak ka izboru odgovarajućih mera za njegovo rešavanje. Zagušenje - i naizgled i u stvarnosti utiče na kretanje ljudi. Saobraćajno zagušenje stvara gubitak vremena, dodatnu potrošnju energije i uzrokuje zagađenje. Uopšteno govoreći, postoje dve grupe faktora koji utiču na zagušenje: (a) faktori na mikro nivou; (b) faktori na makro nivou koji su u vezi sa opštim zahtevima za korišćenjem saobraćajnica.
Zagušenje se "aktivira" na "mikro" nivou (npr. na putevima), a "podstiče" na "makro" nivou. Faktori na mikro nivou predstavljeni su pojavom situacije kada veliki broj ljudi želi da se kreće istovremeno, odnosno kada ima isuviše vozila na ograničenom prostoru kakav je saobraćajnica. Faktori na makro nivou predstavljeni su načinom korišćenja zemljišta, trendovima stepena motorizacije, regionalnim privrednim razvojem, itd. U ovom radu je prikazan detaljan pregled mogućih načina identifikacije i merenja pokazatelja zagušenja na gradskim arterijama na osnovu mernih pokazatelja poput brzine, vremena putovanja/kašnjenja, protoka i nivoa usluge. Pregledom su obuhvaćeni različiti aspekti poput definicija, kriterijuma merenja koji se primenjuju u različitim državama/ organizacijama. Razmotrene su prednosti i mane ovih mera. Osim toga, dat je i kratak kritički osvrt na kriterijume merenja.

Ključne reči: saobraćajno zagušenje, metode prikupljanja podataka, merenje zagušenja. 